\title{
Cytomorphological Characterization of the Backcross Progeny of Synthetic Amphiploid Rice (AABB) and Tetraploid Oryza sativa (AAAA)
}

\author{
Xianhua Zhang ${ }^{1}$, Wei Wang ${ }^{1}$, Junjie Jin ${ }^{1}$, Shengrong Liao $^{1}$, Xiaonan Liu ${ }^{1}$, Zhaojian Song ${ }^{1} \&$ Detian Cai ${ }^{1}$ \\ ${ }^{1}$ College of Life Sciences, Hubei University, Wuhan, China \\ Correspondence: Detian Cai, College of Life Sciences, Hubei University, Wuhan 430062, China. Tel: \\ 86-27-5086-5578. E-mail: caidt8866@sohu.com
}

Received: August 28, 2013 Accepted: September 22, 2013 Online Published: November 15, 2013

doi:10.5539/jas.v5n12p30 URL: http://dx.doi.org/10.5539/jas.v5n12p30

\begin{abstract}
DCW008, a synthetic allopolyploid rice $(2 \mathrm{n}=4 \mathrm{X}=48$, AABB), was obtained from chromosome doubling of interspecific hybrids between Oryza sativa $(2 \mathrm{n}=24, \mathrm{AA})$ and O. punctata $(2 \mathrm{n}=24, \mathrm{BB})$. The $\mathrm{F}_{1}$ and backcross $\left(\mathrm{BC}_{1}\right)$ hybrids were produced by crossing DCW008 as a female parent with a high seed set tetraploid rice Sg99012 - 4X ( $2 \mathrm{n}=4 \mathrm{X}=48$, AAAA). $\mathrm{BC}_{1} \mathrm{~F}_{1}$ and $\mathrm{BC}_{1} \mathrm{~F}_{2}$ overcame many of the wild-type traits of DCW008; they had yellow-hulled grains, seed set ranged from $0 \%$ to $71.31 \%$ and the grain morphology was similar to that of cultivated rice. Variable numbers of chromosomes were observed in pollen mother cells (PMCs) from the $\mathrm{BC}_{1}$ plant. Genomic in situ hybridization (GISH) revealed that the majority of somatic cells and PMCs contained six chromosomes of $O$. punctata with fragment recombination observed in two of them. The backcross selection method employed in this study to generate allopolyploid progeny provides a reliable way of transferring useful genes from wild species into cultivated rice.
\end{abstract}

Keywords: Oryza punctate, backcrosses, synthetic allopolyploid rice, genomic in situ hybridization (GISH), introgression

\section{Introduction}

The genus Oryza is composed of more than 20 species, represented cytogenetically by ten genome groups, including two cultivated species, O. sativa L. and O. glaberrima Steud (Li et al., 2001; Bao et al., 2006). Abundant wild species of Oryza provide extremely valuable genetic resources to broaden the genetic background of cultivated rice (Khush, 1977). Many researchers have, for a long time, tried to use these wild resources but reproductive barriers, especially at the diploid level, make it difficult to cross and transfer useful genes from wild rice to cultivated rice. However, allopolyploids, which have multiple chromosome sets, exhibit high plasticity since they have the evolutionary advantage of possessing additional genetic materials for growth and adaptation. Hence, they may play an important role in the distant hybridization and promote the exploitation of useful genes from wild species. Allopolyploidy has proven very useful in the utilization of genetic resources to increase yields in many crop species (Albertin et al., 2006; Goncharov et al., 2007; Flagel et al., 2008). Furthermore, allopolyploid rice is a versatile material that can be used to study relationships between different genome groups or in research on rice evolution. It can also be used as a bridge for transferring desirable genes into cultivated rice through gene introgression (Cai et al., 2001). This study utilized the synthetic allopolyploid rice DCW008 (AABB) (created by our laboratory and reported by Wang et al. 2013), which exhibits good fertility and advantageous agronomic traits. DCW008 was crossed and backcrossed with the high seed set tetraploid rice Sg99012-4X (AAAA) as a male parent to obtain the backcross derivatives. The genomic components and cytological characteristics of the $\mathrm{BC}_{1}$ hybrids were studied using GISH. Grain yield and other major agronomic traits of $\mathrm{F}_{1}, \mathrm{BC}_{1} \mathrm{~F}_{1}$ and $\mathrm{BC}_{1} \mathrm{~F}_{2}$ were also investigated.

\section{Materials and Methods}

\subsection{Plant Materials}

The synthetic amphiploid rice DCW008 (AABB, $2 n=4 X=48)$ was developed from chromosome doubling of interspecific hybrids between Sgdts96 (Oryza sativa, $2 \mathrm{n}=24$, AA) and O. punctata $(2 \mathrm{n}=24$, BB). The cultivated rice $\mathrm{Sg} 99012$ (O. sativa, AA, $2 \mathrm{n}=2 \mathrm{X}=24$ ) is a japonica rice line stored at the Polyploid Genetics Lab 
of Hubei University, Wuhan, China. Sg99012-4X (AAAA, $2 \mathrm{n}=4 \mathrm{X}=48$ ) is a high seed set tetraploid rice line with a polyploid meiosis stability (PMeS) gene selected by Cai et al. (2007).

\subsection{Crosses and Backcrosses}

DCW008 was used as the female parent in crosses with Sg99012-4X. Hybrid plants were generated through embryo rescue according to the procedure described by Wang et al. (2013). First backcross generations ( $\left.\mathrm{BC}_{1}\right)$ were generated using Sg99012-4X as a recurrent male parent. The progeny were also produced through embryo rescue. The method for the generation of materials is shown in Figure 1.

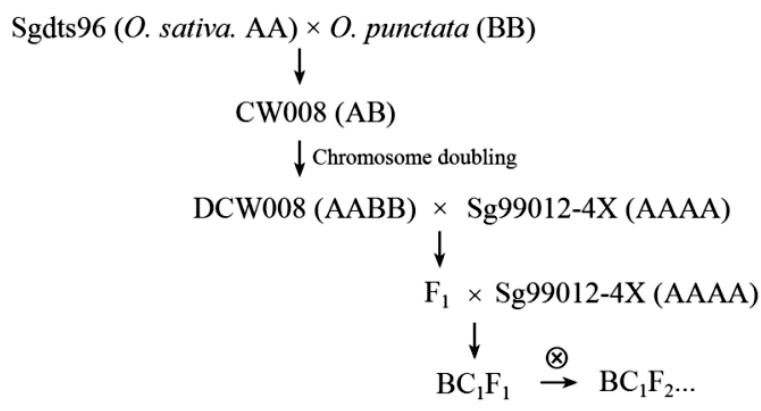

Figure 1. Scheme for production of backcross

\subsection{Cytological Observations and GISH}

Root tips from $\mathrm{F}_{1}$ and backcross progeny were used for the determination of chromosome numbers. Directly fixed young inflorescences were used for meiotic behavior observation ( $\mathrm{Li}$ et al., 1995). Pollen fertility was determined as the percentage of pollen grains stained with $0.2 \%$ fluorescein diacetate (FDA).

For GISH, root tip cells and selected anthers with pollen mother cells (PMCs) at suitable stages were digested for around $4 \mathrm{~h}$ in an enzyme mixture containing $2 \%$ cellulase and $2 \%$ pectinase. Chromosome preparation mainly followed the method described by Yan et al. (1998) with some modifications. Total genomic DNA was extracted from young leaves using the hexadecyltrimethylammonium bromide (CTAB) method. The DNA of O. punctata was fluorescently labeled with bio-11-dUTP using nick translation and used as the probe. The genomic DNA from Sg99012-4X was sheared by autoclaving for 5 min and used as the block. In situ hybridization was carried out according to the method of Leitch et al. (1990).

\subsection{Morphological Observations}

The key morphological traits of plant height, spike number and length, grain length and width, awn length, shattering trait, seed color and seed set were investigated. Recording methods and standards were set according to the protocols of Gai (1996).

\section{Results}

\section{1 $F_{1}$ Hybrids and Backcross Progeny}

Seed set in the DCW008 $\times$ Sg99012-4X cross was $11.73 \%$ and the germination of rescued embryos was $61.90 \%$. Twelve $\mathrm{F}_{1}$ hybrid plants were obtained in total. The seed set upon backcrossing the $\mathrm{F}_{1}$ hybrids with the recurrent female parent ranged from $4.38 \%$ to $6.25 \%$ across different years. A total of $31 \mathrm{BC}_{1} \mathrm{~F}_{1}$ embryos were rescued, but only 10 germinated with a mean germination frequency of $34.10 \%$. Six $\mathrm{BC}_{1} \mathrm{~F}_{1}$ plants survived in total (Table 1 ). 
Table1. Seed set and number of plants obtained in the synthetic allopolyploid rice and Sg99012-4X cross, and backcross progeny through embryo rescue

\begin{tabular}{|c|c|c|c|c|c|c|c|}
\hline \multirow{2}{*}{ Generation } & \multirow{2}{*}{$\begin{array}{c}\text { Spikelets } \\
\text { pollinated (No.) }\end{array}$} & \multicolumn{2}{|c|}{ Seed set $(\%)$} & \multirow{2}{*}{$\begin{array}{l}\text { Embryos cultured } \\
\text { (No.) }\end{array}$} & \multicolumn{2}{|c|}{ Germination } & \multirow{2}{*}{$\begin{array}{l}\text { Plants obtained } \\
\text { (No.) }\end{array}$} \\
\hline & & (No.) & $(\%)$ & & (No.) & $(\%)$ & \\
\hline $\mathrm{F}_{1}$ & 179 & 21 & 11.73 & 21 & 13 & 61.90 & 12 \\
\hline \multirow[t]{3}{*}{$\mathrm{BC} 1 \mathrm{~F}_{1}$} & $112^{*}$ & $7^{*}$ & $6.25^{*}$ & 7 & 3 & 42.86 & 1 \\
\hline & $297^{* *}$ & $13^{* *}$ & $4.38^{* *}$ & 13 & 3 & 23.08 & 3 \\
\hline & $206^{* * *}$ & $11^{* * *}$ & $5.33^{* * *}$ & 11 & 4 & 36.36 & 2 \\
\hline
\end{tabular}

Note: *Recorded in Hainan, China, April, 2011; **Recorded in Wuhan, China, August, 2012; *** Recorded in Wuhan, China, April, 2012. All embryos were rescued in Hubei University, Wuhan, China.

\subsection{Morphology of $F_{1}$ Plants and Backcross Progeny}

The majority of the $\mathrm{F}_{1}$ plants exhibited matroclinous morphology. All were of tall stature and tillering (Figure 2A). They had grain-shattering traits, long red awns, purple stigma and black hulled-grains. $F_{1}$ plants had no seed set after selfing although immature embryos could occasionally be observed. Compared with $\mathrm{F}_{1}$ plants, the $\mathrm{BC}_{1}$ plants' morphology was more similar to that of Sg99012-4X. FDA staining indicated most of the pollen was fertile (Figure 2B). Anthers were normal and full (Figure 2C) and the seed setting rate of the $\mathrm{BC}_{1} \mathrm{~F}_{1}$ plants ranged from $6.90 \%$ to $21.33 \%$ (Table 2). The shattering traits of $\mathrm{BC}_{1} \mathrm{~F}_{1}$ were normal and the grain hull was yellow (Figure 2D, d1). Segregation occurred amongst the $\mathrm{BC}_{1} \mathrm{~F}_{2}$ plants. Using grain hull color as an example, four plants (plant Nos. $6,8,12$ and 19) produced black-hulled grains, but the remaining progeny had yellow-hulled grains. The grain-shattering trait also segregated into the normal and shattering phenotypes. The $\mathrm{BC}_{1} \mathrm{~F}_{2}$ progeny had differing levels of seed set after selfing; six individuals (25\%) had less than 5\% seed set whereas the remaining plants (75\%) had a seed set greater than 5\%. Plant Nos. 3 and 7 had very high seed sets ( $71.31 \%$ and $61.32 \%$, respectively).
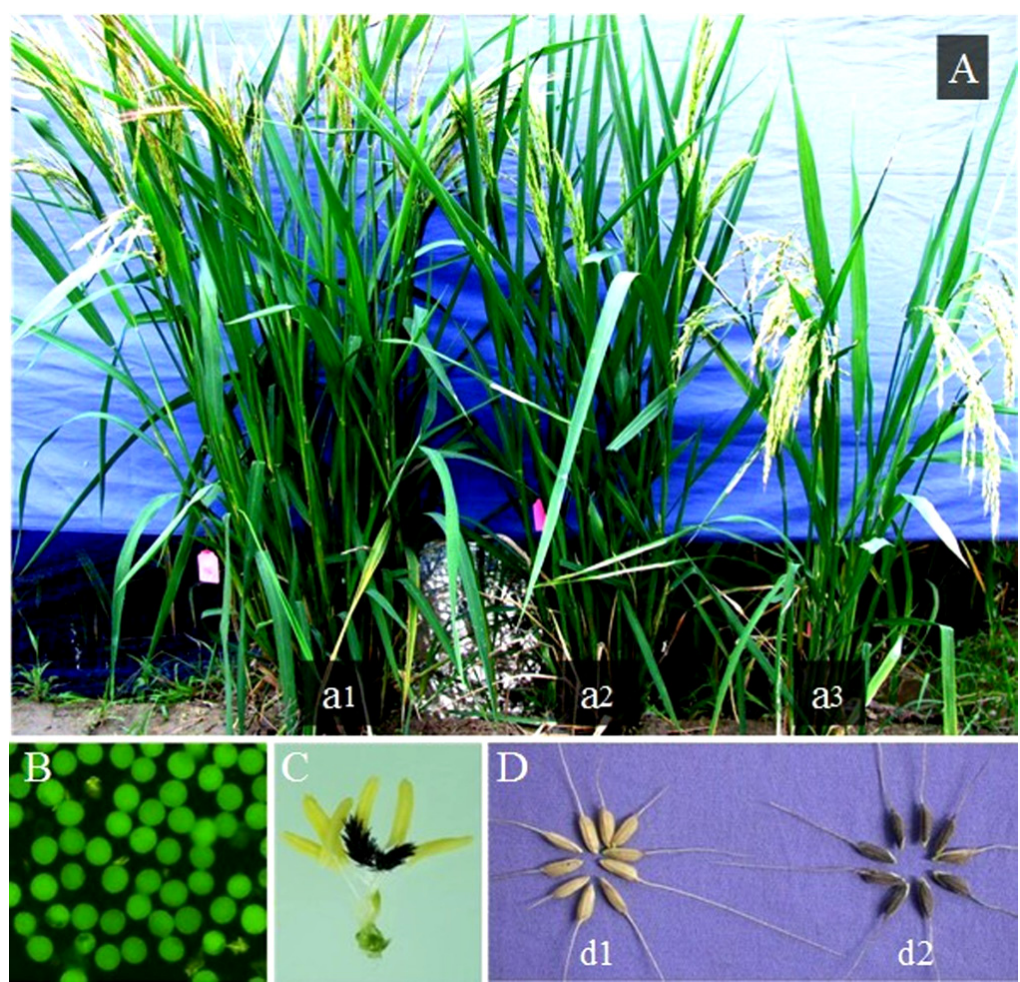

Figure 2. (A) Overall morphology of the hybrids. a1: $\mathrm{F}_{1} ; \mathrm{a} 2: \mathrm{BC}_{1} \mathrm{~F}_{1} ; \mathrm{a} 3: \mathrm{Sg} 99012-4 \mathrm{x}$. (B) Pollen staining by FDA. (C) Glumous flower of $\mathrm{BC}_{1} \mathrm{~F}_{1}$ (no outer glume). (D) Seeds of $\mathrm{BC}_{1} \mathrm{~F}_{1}$ and allopolyploid rice (AABB). d1: yellow, seeds of $\mathrm{BC}_{1} \mathrm{~F}_{1}$; $\mathrm{d} 2$ : black, seeds of $\mathrm{AABB}$ 
Table 2. Agronomic traits of $\mathrm{F}_{1}, \mathrm{BC}_{1} \mathrm{~F}_{1}$ and $\mathrm{BC}_{1} \mathrm{~F}_{2}$ from synthetic allopolyploid rice $\times \mathrm{Sg} 99012-4 \mathrm{X}$

\begin{tabular}{|c|c|c|c|c|c|c|c|c|c|}
\hline \multicolumn{2}{|c|}{ Materials } & $\begin{array}{l}\text { Plant } \\
\text { height } \\
(\mathrm{cm})\end{array}$ & $\begin{array}{l}\text { Spike } \\
\text { number }\end{array}$ & $\begin{array}{c}\text { Spike } \\
\text { length } \\
(\mathrm{cm})\end{array}$ & $\begin{array}{c}\text { Grain } \\
\text { length / } \\
\text { width } \\
(\mathrm{cm})\end{array}$ & $\begin{array}{c}\text { Awn } \\
\text { length } \\
(\mathrm{cm})\end{array}$ & $\begin{array}{c}\text { Seed } \\
\text { set }(\%)\end{array}$ & $\begin{array}{l}\text { Seed } \\
\text { color }\end{array}$ & $\begin{array}{c}\text { Shattering } \\
\text { trait }\end{array}$ \\
\hline \multicolumn{2}{|c|}{ Sg99012-4x } & 83.79 & 8 & 26.13 & $1.00 / 0.31$ & $0-2.58$ & 86.11 & yellow & Normal \\
\hline \multicolumn{2}{|l|}{$\mathrm{F}_{1}$} & 109.22 & 17 & 28.60 & $0.90 / 0.35$ & $0.31-8.05$ & 0 & black & Shattering \\
\hline \multirow[t]{6}{*}{$\mathrm{BC}_{1} \mathrm{~F}_{1}$} & Plant $1^{*}$ & 96.20 & 12 & 25.30 & $1.00 / 0.30$ & $0.11-2.80$ & 9.95 & yellow & Normal \\
\hline & plant $2^{* *}$ & 79.62 & 13 & 21.18 & $1.00 / 0.29$ & $0.23-3.09$ & 15.92 & yellow & Normal \\
\hline & plant $3^{* *}$ & 82.33 & 9 & 19.89 & $1.05 / 0.30$ & $0.32-6.75$ & 21.33 & yellow & Normal \\
\hline & plant $4^{* *}$ & 83.97 & 10 & 21.36 & $1.00 / 0.29$ & $0.44-5.28$ & 12.74 & yellow & Normal \\
\hline & plant $5^{* * *}$ & 94.30 & 18 & 22.44 & $0.95 / 0.33$ & $0.17-3.51$ & 6.90 & yellow & Normal \\
\hline & plant $6^{* * *}$ & 105.19 & 14 & 29.72 & $1.00 / 0.33$ & $0.06-2.96$ & 18.37 & yellow & Normal \\
\hline \multirow[t]{24}{*}{$\mathrm{BC}_{1} \mathrm{~F}_{2}$} & Plant 1 & 116.11 & 15 & 33.11 & $0.85 / 0.31$ & $0-2.60$ & 18.37 & yellow & Normal \\
\hline & plant 2 & 108.55 & 13 & 30.15 & $1.10 / 0.30$ & $0.61-2.20$ & 32.67 & yellow & Normal \\
\hline & plant 3 & 93.37 & 15 & 25.23 & $1.00 / 0.30$ & $0.30-2.70$ & 71.31 & yellow & Normal \\
\hline & plant 4 & 85.30 & 12 & 25.77 & $1.00 / 0.35$ & $0.10-1.61$ & 33.82 & yellow & Normal \\
\hline & plant 5 & 78.60 & 9 & 28.42 & $0.95 / 0.35$ & $0.51-2.62$ & 28.89 & yellow & Normal \\
\hline & plant 6 & 70.67 & 16 & 26.30 & $1.00 / 0.35$ & $1.62-4.70$ & 17.46 & black & Shattering \\
\hline & plant 7 & 80.50 & 15 & 23.50 & $1.10 / 0.35$ & $1.20-6.94$ & 61.32 & yellow & Normal \\
\hline & plant 8 & 95.25 & 13 & 14.70 & $0.90 / 0.38$ & $0.10-0.90$ & 2.63 & black & Shattering \\
\hline & plant 9 & 103.36 & 11 & 25.89 & $1.00 / 0.35$ & $0.33-6.10$ & 46.81 & yellow & Normal \\
\hline & plant 10 & 92.60 & 16 & 23.95 & $0.95 / 0.33$ & $0.10-3.21$ & 20.24 & yellow & Normal \\
\hline & plant 11 & 90.50 & 9 & 24.45 & $1.00 / 0.35$ & $0.66-4.60$ & 25.51 & yellow & Normal \\
\hline & plant 12 & 79.8 & 14 & 23.90 & $1.00 / 0.35$ & $0-3.15$ & 0 & black & Shattering \\
\hline & plant 13 & 86.47 & 11 & 21.84 & $1.00 / 0.35$ & $0-2.13$ & 3.85 & yellow & Normal \\
\hline & plant 14 & 110.96 & 9 & 27.40 & $0.91 / 0.38$ & $0.31-4.90$ & 3.16 & yellow & Normal \\
\hline & plant 15 & 74.33 & 13 & 19.26 & $0.92 / 0.38$ & $0.11-3.40$ & 38.53 & yellow & Normal \\
\hline & plant 16 & 95.20 & 17 & 26.19 & $0.98 / 0.36$ & $0-1.10$ & 2.91 & yellow & Shattering \\
\hline & plant 17 & 106.69 & 13 & 22.10 & $0.98 / 0.35$ & $0-0.61$ & 36.52 & yellow & Normal \\
\hline & plant 18 & 102.53 & 18 & 25.40 & $1.00 / 0.40$ & $0-1.00$ & 41.13 & yellow & Normal \\
\hline & plant 19 & 86.30 & 15 & 23.80 & $1.00 / 0.35$ & $0.21-1.75$ & 5.85 & black & Shattering \\
\hline & plant 20 & 99.60 & 11 & 25.35 & $1.00 / 0.35$ & $1.20-6.65$ & 19.26 & yellow & Normal \\
\hline & plant 21 & 79.05 & 9 & 20.00 & $0.95 / 0.36$ & $0.60-2.80$ & 0 & yellow & Normal \\
\hline & plant 22 & 92.90 & 12 & 21.30 & $0.90 / 0.38$ & $0.34-4.50$ & 29.75 & yellow & Shattering \\
\hline & plant 23 & 88.26 & 12 & 22.27 & $0.90 / 0.38$ & $0-0.92$ & 10.62 & yellow & Normal \\
\hline & plant 24 & 86.54 & 15 & 23.80 & $1.00 / 0.38$ & $0-0.41$ & 22.14 & yellow & Normal \\
\hline
\end{tabular}

Note: *Recorded in Wuhan, China, 2011; **Recorded in Hainan, China, 2012; *** Recorded in Wuhan, China, 2012. The $\mathrm{BC}_{1} \mathrm{~F}_{2}$ plants were the progeny of plant 1 of $\mathrm{BC}_{1} \mathrm{~F}_{1}$.

\subsection{Meiotic Behavior of the $B C_{1} F_{l}$ Plant}

The $\mathrm{BC}_{1} \mathrm{~F}_{1}$ plant generally showed irregular meiosis. Univalent, bivalent, trivalent, quadrivalent and multivalent chromosomes could be observed (Figure 3, b-d). There were mainly four types of chromosome pairing at diakinesis/ metaphase I (Table 3). Lagging chromosomes were observed frequently in PMCs at metaphase I and 
anaphase I (Figure 3, e-f). Four lagging chromosomes were observed most frequently (42.31\%) with one lagging chromosome seen the most infrequently (3.85\%; Table 4). Chromosomal bridges were also observed in some PMCs at anaphase I (Figure 3, g).

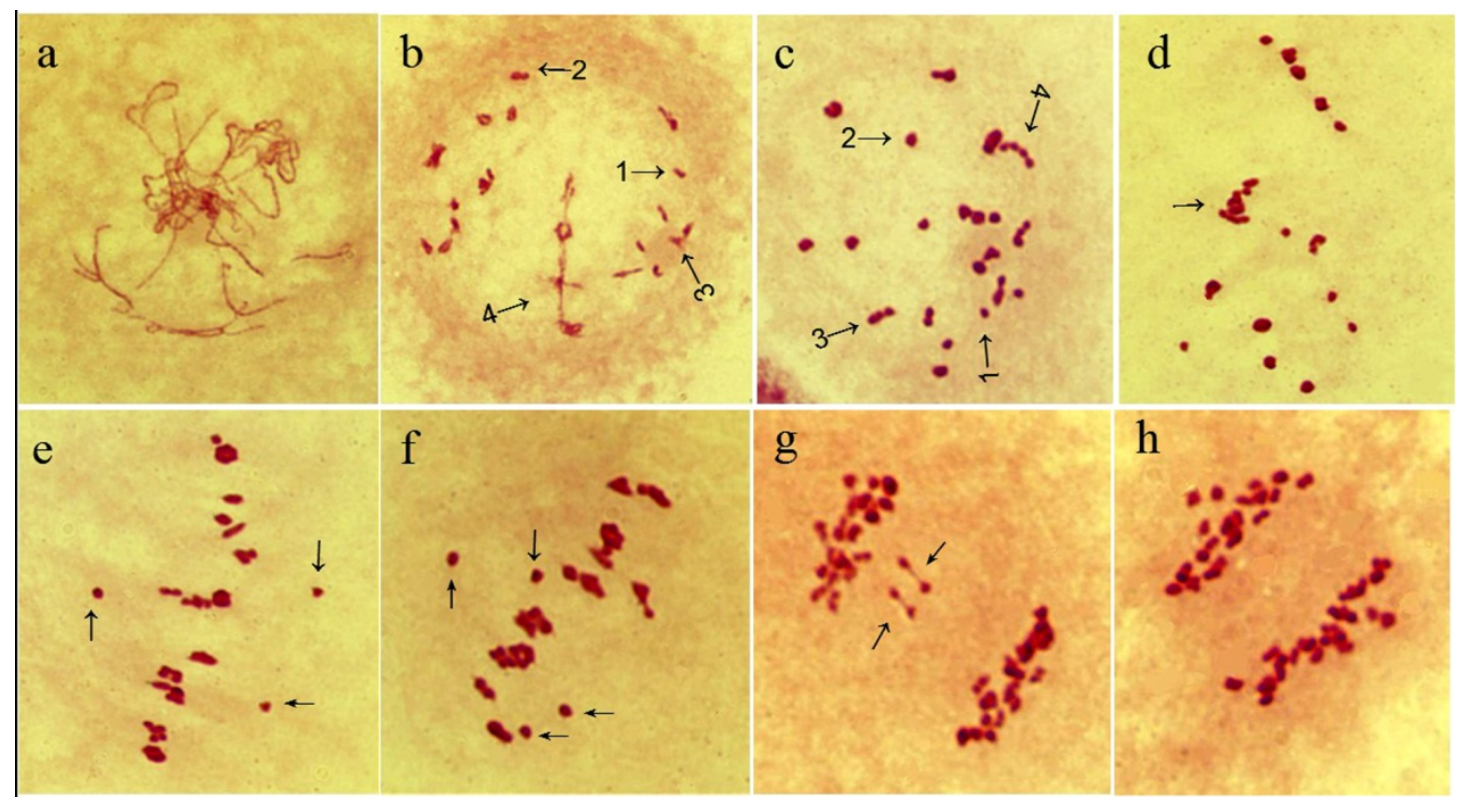

Figure 3. Meiotic aspects of the $\mathrm{BC}_{1} \mathrm{~F}_{1}$ from synthetic allopolyploid rice (AABB) $\times \mathrm{Sg} 99012-4 \mathrm{X}($ O. sativa, AAAA, $2 \mathrm{n}=4 \mathrm{X}=48$ ). (a) zygotene (prophase I); (b)chromosomes at diplotene (prophase I), arrow 1: univalent; arrow 2: bivalent; arrow 3: quadrivalent; arrow 4: multivalent, c-f: Chromosomes at diakinesis (prophase I), (c) arrow 1: univalent; arrow 2: bivalent; arrow 3: trivalent; arrow 4: quadrivalent, (d) arrow: multivalent. e-f: Two PMCs at metaphase I showing lagging chromosomes (arrows). g-h: Two anther PMCs at anaphase I. (g) with two chromosome bridges; arrows. (h) normal

Table 3. Chromosome pairing of the backcross-1 plant having $2 \mathrm{n}=48$

\begin{tabular}{llll}
\hline Types & Number of PMCs & Chromosome pairing & Percentage (\%) \\
\hline Type 1 & 27 & $4.0 \mathrm{I}+7.69 \mathrm{II}+7.15 \mathrm{IV}$ & 27.84 \\
Type 2 & 36 & $3.72 \mathrm{I}+6.35 \mathrm{II}+3.62 \mathrm{III}+5.18 \mathrm{IV}$ & 37.11 \\
Type 3 & 23 & $4.17 \mathrm{I}+1.42 \mathrm{II}+1.67 \mathrm{III}+5.50 \mathrm{IV}+2.33$ multivalent & 23.71 \\
others & 11 & & 11.34 \\
\hline
\end{tabular}

Note: I univalent, II bivalent, III trivalent IV, quadrivalent.

Table 4. Lagging chromosomes of the meiotic metaphase I and anaphase I of the backcross-1 plant

\begin{tabular}{ccc}
\hline Number of lagging chromosomes & Number of PMCs & Percentage (\%) \\
\hline 1 & 5 & 3.85 \\
2 & 14 & 10.77 \\
3 & 24 & 18.46 \\
4 & 55 & 42.31 \\
5 & 32 & 24.62 \\
\hline
\end{tabular}

\subsection{GISH Analysis of the $B C_{1} F_{1}$ Plant}

The chromosome number in root tips of the $\mathrm{BCF}_{1}$ plant was $2 \mathrm{n}=48$. GISH analysis indicated that four chromosomes were wholly labeled by the $O$. punctata probe. Two chromosomes were partly labeled (Figure 4, 
a1-2). In some diakinesis PMCs four univalents were fully labeled and two bivalents were partly labeled but the attached fragments were unlabeled (Figure 4, b1-2). At metaphase I of some PMCs, two partly labeled bivalents appeared in the equatorial plate, whilst four lagging chromosomes were labeled. In addition, there was another unlabeled lagging chromosome (Figure 4, c1-2).
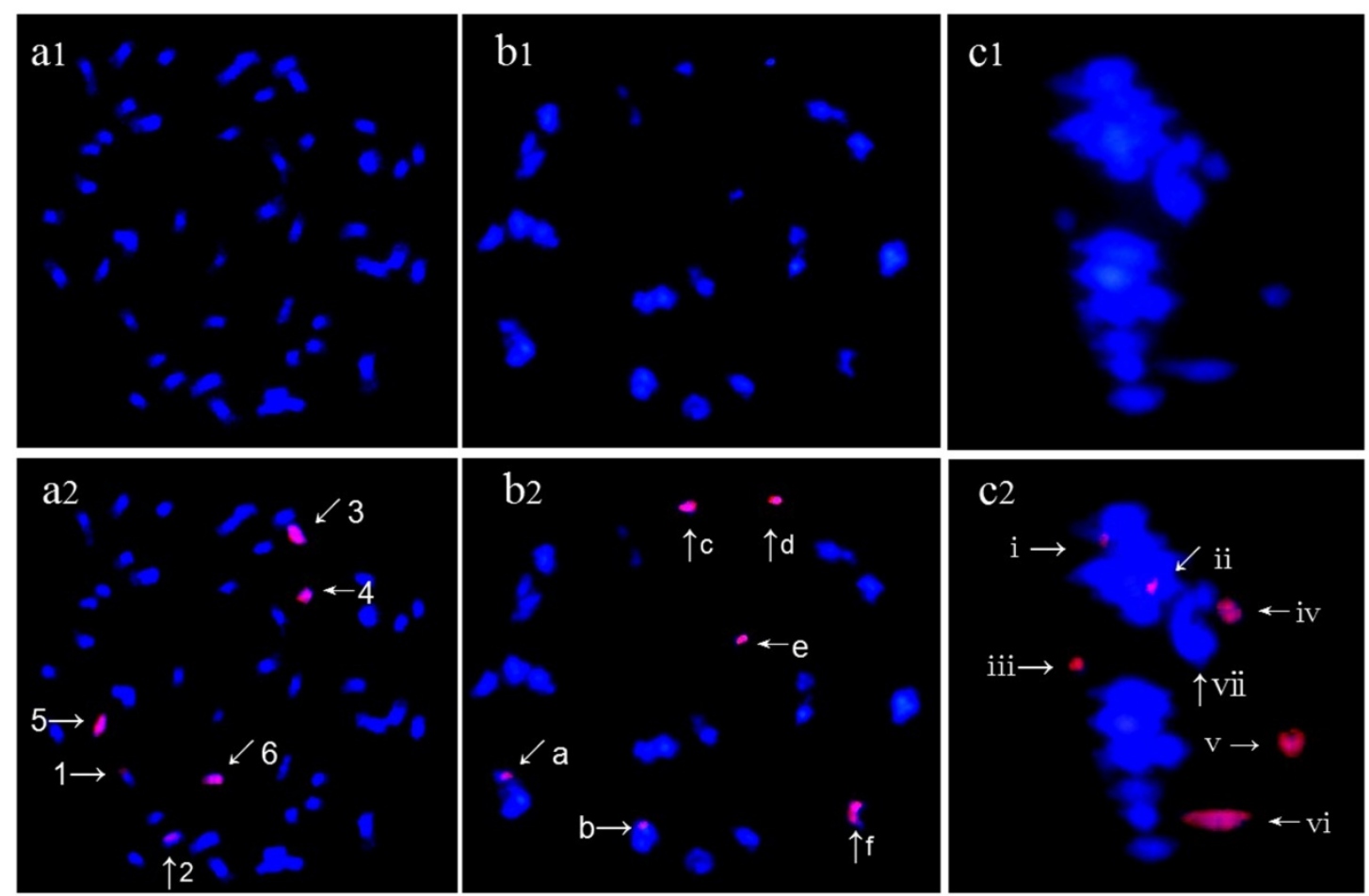

Figure 4. GISH analysis. DAPI (blue) and merged (red signals from the O. punctata) images. a1 - a2:

Chromosomes of somatic cell from $\mathrm{BC}_{1} \mathrm{~F}_{1}(2 \mathrm{n}=4 \mathrm{X}=48)$. (a1) DAPI image; (a2) Two chromosomes (arrows 1, 2) were partly labeled. 4 chromosomes were fully labeled (arrows 3-5). b1 - b2: one PMC at diakinesis. (b1) DAPI image; (b2) Two bivalent (arrows a, b) were labeled but the attached fragments were unlabeled. The univalents

(arrows c-f) were fully labeled. c1 - c2: one PMC at metaphase I. (c1) DAPI image. (c2) Two partly labeled bivalent arranged in equatorial plate (arrows $\mathrm{i}$, ii ). Four Lagging chromosomes were fully labeled (arrows iiivi). There was another unlabeled laggard (arrow vii)

\section{Discussion}

\subsection{Utilization of Desirable Genes from Wild Rice Resources}

The wild Oryza species are an important source of desirable genes for resistance to major pests and diseases and for tolerance to various abiotic stresses. As such they form an extremely valuable genetic resource (Flagel et al., 2008; Multani et al., 2003). Researchers have attempted to use these wild resources for many decades. During the 1970's several interspecific hybrids and amphiploids were produced in order to introgress novel genes from wild species into cultivated rice (Khush, 1977). Many disease and insect resistance genes introgressed from wild species have been used in rice breeding and several varieties carrying these genes have now been released (Jena and Khush, 1989; Amante-Bordeos et al., 1992; Multani et al., 1994). Some wild species genes (Xa 21, Bph 18) have also been used in marker assisted selection (Singh et al., 2001; Jena et al., 2006). The purpose of this study was to obtain new rice germplasm and to introgress genes from O. punctata on a tetraploid level. In this investigation, the $\mathrm{F}_{1}$ plants were sterile. However, improvements in three agronomically important traits were observed in the $\mathrm{BC}_{1} \mathrm{~F}_{1}$ and $\mathrm{BC}_{1} \mathrm{~F}_{2}$ plants- increased seed setting rate, normal shattering trait and short plant height. New polyploid rice lines $(2 \mathrm{n}=48)$, monosomic alien addition lines or gene introgression lines with $O$. punctata chromosome fragments or genes will now be obtained from this backcross progeny. 


\subsection{Effects of allopolyploidy in Crop Breeding}

Polyploidy is an evolutionary innovation in many plant and some animal species (Ni et al., 2009). Allopolyploid plants are hybrids that contain two copies of the genome from each parent (Comai, 2000). Many commercially important crops such as wheat, cotton and canola are allopolyploids (A. R. Leitch, \& I. J. Leitch, 2008; Chen, 2007). In addition, some allopolyploid rice species already exist in the wild. Synthetic allopolyploids should further enrich existing rice resources. Moreover, they will be beneficial for both the protection of wild resources and the storage and use of wild germplasms (Sangiacomo \& Sullivian 1994; Kazi et al., 1996; Ge \& Li, 2007; Goncharov et al., 2007; Yao et al., 2012). From an evolutionary perspective, different genomic combinations and polyploidization reflects the general direction of crop evolution (Cai et al., 2001). Allopolyploids possess the evolutionary advantage of having double the genetic material for growth and adaptation and can overcome the reproductive barrier of wild and cultivated species (Wang et al., 2013). Hence, they may play an important role in the distant hybridization and assist plant breeders in the utilization of genetic resources from wild species.

\section{Conclusions}

Obtaining desirable genes from wild species is an important approach in plant breeding. In combination with wild cross, polyploidization and backcrossing, the polyploids or allopolyploids will assist plant breeders in the utilization of genetic resources from wild species.

\section{Acknowledgements}

The study was supported by the National Natural Science Foundation of China (Grant No. 31271690, 31270356), the National 'Twelfth Five-Year' Support Plan for Science \& Technology of China (No. 2011BAD35B02), the Natural Science Foundation of Hubei Province (Grant No. 2009CDA081), the Science and Technology Research Program of the Education Department of Hubei Province (Grant No. Q20131006)

\section{References}

Albertin, W., Balliau, P., Brabant, T., Chèvre, A. M., Eber, F., Malosse, C., \& Thiellement, H. (2006). Numerous and rapid nonstochastic modifications of gene products in newly synthesized Brassica napus allotetraploids. Genetics, 173, 1101-1113. http://dx.doi.org/10.1534/genetics.106.057554

Ali, M. L., Sanchez, L. P., Yu, S. B., Lorieux, M., \& Eizenga, G. C. (2010). Chromosome Segment Substitution Lines: A Powerful Tool for the Introgression of Valuable Genes from Oryza Wild Species into Cultivated Rice (O. sativa). Rice., 3, 218-234. http://dx.doi.org/10.1007/s12284-010-9058-3

Amante-Bordeos, A., Sitch, L. A., Nelson, R., Dalmaeio, R. D., Oliva, N. P., Aswidinnoor, H., \& Leung, H. (1992). Transfer of bacterial blight and blast resistance from the tetraploid wild rice Oryza minuta to cultivated rice, Oryza sativa. Theor Appl Genet., 84, 345-354. http://dx.doi.org/10.1007/BF00229493

Bao, Y., Zhou, H. F., Hong, D. Y., \& Ge, S. (2006). Genetic Diversity and Evolutionary Relationships of Oryza Species with the B- and C-Genomes as Revealed by SSR Markers. Journal of Plant Biology, 49(5), 339-347. http://dx.doi.org/10.1007/BF03178809

Cai, D. T., Chen, J. G., Chen, D. L., Dai, B. C., Zhang, W., Song, Z. J.,... He, Y. C. (2007). The breeding of two polyploid rice lines with the characteristic of polyploid meiosis stability. Science in China Series C: Life Sciences, 50, 356-366. http://dx.doi.org/10.1007/s11427-007-0049-6

Cai, D. T., Yuan, L. P., \& Lu, X. G. (2001). A new strategy of rice breeding in the $21^{\text {st }}$ century. Searching a new pathway of rice breeding by utilization of double heterosis of wide cross and polyploidization. Acta Agronomica Sinica, 27(1), 110-116.

Chen, Z. J. (2007). Genetic and epigenetic mechanisms for gene expression and phenotypic variation in plant polyploids. Annu Rev Plant Biol., 58, 377-406. http://dx.doi.org/10.1146/annurev.arplant.58.032806.103835

Comai, L. (2000). Genetic and epigenetic interactions in allopolyploid plants. Plant Molecular Biology, 43, 387-399. http://dx.doi.org/10.1023/A:1006480722854

Flagel, L., Udall, J., Nettleton, D., \& Wendel, J. (2008). Duplicate gene expression in allopolyploid Gossypium reveals two temporally distinct phases of expression evolution. BMC Biol., $6,16$. http://dx.doi.org/10.1186/1741-7007-6-16

Gai, J. Y. (1996). Crop Breeding (special) (pp. 43-45). Beijing: China Agriculture Press.

Ge, X. H., \& Li, Z. Y. (2007). Intra- and intergenomic homology of B-genome chromosomes in trigenomic combinations of the cultivated Brassica species revealed by GISH analysis. Chromosome Research, 15, 849-861. http://dx.doi.org/10.1007/s10577-007-1168-4 
Goncharov, N. P., Bannikova, S. V., \& Kawahara, T. (2007). Wheat artificial amphiploids involving the Triticum timopheevii genome: their studies, preservation and reproduction. Genet Resour Crop Evol., 54, 1507-1516. http://dx.doi.org/10.1007/s10722-006-9141-1

Jena, K. K., \& Khush, G. S. (1989). Monosomic alien addition lines of rice: production, morphology, cytology and breeding behaviour. Genome, 32, 449-455. http://dx.doi.org/10.1139/g89-468

Jena, K. K., Jeung, J. U., Lee, J. H., Choi, H. C., \& Brar, D. S. (2006). High-resolution mapping of a new brown planthopper (BPH) resistance gene, Bph18(t), and marker-assisted selection for BPH resistance in rice (Oryza sativa L.). Theor Appl Genet., 112, 288-297. http://dx.doi.org/10.1007/s00122-005-0127-8

Kazi, M. A., Rosas, V., \& Roldan, S. (1996). Conservation of the genetic variation of Triticum tauschii (Coss.) Schmalh. (Aegilops squarrosa auct. non L.) in synthetic hexaploid wheats (T. Sturgidum L. s. Lat. $\times T$. Tauschii; $2 \mathrm{n}=6 \mathrm{x}=42$, AABBDD) and its potential utilization for wheat improvement. Genetic Resources and Crop Evolution, 43, 129-134. http://dx.doi.org/10.1007/BF00126756

Khush, G. S. (1977). Disease and insect resistance in rice. Adv Agron., 29, $265-341$. http://dx.doi.org/10.1016/S0065-2113(08)60221-7

Leitch, A. R., \& Leitch, I. J. (2008). Genomic plasticity and the diversity of polyploid plants. Science, 320, 481-48. http://dx.doi.org/10.1126/science. 1153585

Leitch, A. R., Mosgoller, W., Schwarzacher, T., Bennett, M. D., \& Heslop-Harrison, J. S. (1990). Genomic in situ hybridization to sectioned nuclei shows chromosome domains in grass hybrids. Cell Sci., 95, 335-341.

Li, C. B., Zhang, D. M., Ge, S., Lu, B. R., \& Hong, D. Y. (2001). Identification of genome constitution of Oryza malampuzhaensis, O. minuta, and O. punctata by multicolor genomic in situ hybridization. Theor Appl Genet. http://dx.doi.org/103:204-211.10.1007/s001220100563

Li, Z., Liu, H. L., \& Luo, P. (1995). Production and cytogenetics of intergeneric hybrids between Brassica napus and Orychophragmus violaceus. Theor Appl Genet., 91, 131-136. http://dx.doi.org/10.1007/BF00220869

Multani, D. S., Jena, K. K., Brar, D. S., Reyes, B. G., Angeles E. R., \& Khush, G. S. (1994). Development of monosomic alien addition lines and introgression of genes from Oryza australiensis Domin. to cultivated rice O. sativa L. Theor Appl Genet., 88, 102-109. http://dx.doi.org/10.1007/BF00222401

Multani, D. S., Khush, G. S., Delos Reyes, B. G., \& Brar, D. S. (2003). Alien genes introgression and development of monosomic alien addition lines from Oryza latifolia Desv. to rice, Oryza sativa L. Theor Appl Genet., 107, 395-405. http://dx.doi.org/10.1007/s00122-003-1214-3

Ni, Z. F., Kim, E. D., Ha, M., Lackey, E., Liu, J. X., Zhang, Y. R., ... Chen, Z. J. (2009). Altered circadian rhythms regulate growth vigor in hybrids and allopolyploids. Nature, 457(7227), $327-331$. http://dx.doi.org/10.1038/nature07523

Sangiacomo, M. A., \& Sullivian, J. A. (1994). Introgression of wild species into the cultivated strawberry using synthetic octoploids. Theor Appl Genet., 88, 349-354. http://dx.doi.org/10.1007/BF00223644

Singh, S., Sidhu, J. S., Huang, H., Vikal, Y., Li, Z., Brar, D. S., ... Khush, G. S. (2001). Pyramiding three bacterial blight resistance genes ( $x a 5, x a 13$ and Xa21) using marker-assisted selection into indica rice cultivar PR106. Theor Appl Genet., 102, 1011-1015. http://dx.doi.org/10.1007/s001220000495

Wang, A. Y., Zhang, X. H., Yang, C. H., Song, Z. J., Du, C. Q., Chen, D. L., ... Cai, D. T. (2013). Development and characterization of synthetic amphiploid (AABB) between Oryza sativa and Oryza punctata. Euphytica, 189, 1-8. http://dx.doi.org/10.1007/s10681-012-0821-y

Yan, H. M., Song, Y. C., Li, L. J., Bi, X. Z., \& Fu, B. Y. (1998). Physical location of rice Pi-5(t), Glh and RTSV genens by ISH of BAC clones. Wuhan Univ J Nat Sci., 3, 226-230. http://dx.doi.org/10.1007/BF02827558

Yao, X. C., Xian hong, G. E., \& Li, Z. Y. (2012). Cytology of Brassica allohexaploids and BC2 progenies from B. napus and B. Maurorum. Chinese journal of oil crop sciences, 34(1), 016- 020.

\section{Copyrights}

Copyright for this article is retained by the author(s), with first publication rights granted to the journal.

This is an open-access article distributed under the terms and conditions of the Creative Commons Attribution license (http://creativecommons.org/licenses/by/3.0/). 